\author{
S.V. Zdolnikova, A.V. Babkin
}

\title{
INTEGRATED INDUSTRIAL STRUCTURES AS A TOOL FOR IMPLEMENTING THE SYNERGETIC APPROACH TO FORMING THE INDUSTRIAL POLICY
}

\author{
С.В. Здольникова, А.В. Бабкин \\ ИНТЕГРИРОВАННЫЕ ПРОМЫШЛЕННЫЕ СТРУКТУРЫ \\ КАК ИНСТРУМЕНТ РЕАЛИЗАЦИИ СИНЕРГЕТИЧЕСКОГО ПОДХОДА \\ ПРИ ФОРМИРОВАНИИ ПРОМЫШЛЕННОЙ ПОЛИТИКИ
}

In modern market conditions the creation of an effective national economy largely is provided by the system stimulating innovation and technological development of the industry, while the government is one of the most effective factors shaping the conditions of existence and the practical application of innovation in production and other spheres of society. This paper considers the integration of economic entities as a means of forming state industrial policy. The purpose of the study is to show the interconnection of integrated industrial structures (IIS) and implementation of the synergetic approach in shaping industrial policy: to substantiate the effects of industrial policy on the growing trend of the formation of IIS, on the one hand, and the impact of synergies from the creation of the IIS on the development of Russian industry, on the other hand. The authors used statistical methods to assess the impact of IIS activities on the level of innovative development of the national economy, as well as applied basic concepts of marginal analysis to identify the conditions of appearance of synergetic effect in the IIS. The study found that the use of the synergetic concept in the formation of industrial policy is justified and necessary at this stage of development of the national economy, and the IIS can be considered as a tool for the realization of the synergetic approach in shaping the industrial policy. In the future, detailed elaboration of the methodology for assessing the synergetic effect of the IIS will be required, as well as development of organizational-economic mechanism of management of innovative potential of IPS as an integral part of the innovative potential of Russian industry as a whole.

INTEGRATED INDUSTRIAL STRUCTURE; INDUSTRIAL POLICY; SYNERGISTIC APPROACH TO MANAGEMENT; SYNERGIES; INNOVATION DEVELOPMENT.

В современных рыночных условиях создание эффективной национальной экономики в значительной степени обеспечивается за счет системного стимулирования инноваций и технологического развития промышленности, при этом государство является одним из действенных факторов, формирующих условия существования и практического применения инноваций в производстве и других сферах жизни общества. Данная статья посвящена рассмотрению интеграции хозяйствующих субъектов как одного из инструментов формирования государственной промышленной политики. Цель исследования - показать взаимосвязь деятельности интегрированных промышленных структур (ИПС) и реализации синергетического подхода при формировании промышленной политики: обосновать воздействие промышленной политики на усиление тенденции к образованию ИПС, с одной стороны, и воздействие синергетического эффекта от создания ИПС на развитие российской промышленности, с другой стороны. Авторами были использованы статистические методы для оценки влияния деятельности ИПС на уровень инновационного развития национальной экономики, а также применены основные положения концепции маржинального анализа для выявления условий появления синергетического эффекта в ИПС. В результате исследования было установлено, что применение синергетической концепции при формировании промышленной политики является оправданным и необходимым на данном этапе развития национальной экономики, а ИПС, могут быть рассмотрены в качестве инструмента реализации синергетического подхода при формированию промышленной политики. В дальнейшем потребуется детальная проработка методики оценки синергетического эффекта ИПС, а также разработка организационно-экономического механизма управления инновационным потенциалом ИПС как составной части инновационного потенциала российской промышленности в целом.

ИНТЕГРИРОВАННЫЕ ПРОМЫШЛЕННЫЕ СТРУКТУРЫ; ПРОМЫШЛЕННАЯ ПОЛИТИКА; СИНЕРГЕТИЧЕСКИЙ ПОДХОД К УПРАВЛЕНИЮ; СИНЕРГЕТИЧЕСКИЙ ЭФФЕКТ; ИННОВАЦИОННОЕ РАЗВИТИЕ. 
The relevance of the research. The beginning of the 21st century has been marked by the advent of technological, marketing, organizational and other innovations. On the one hand, it contributed to the development of science-intensive industries, on the other hand, it made the business environment unsteady and unpredictable. Changes in market conditions lead to changes in industrial policy currently aimed at creating high-tech, competitive industry, ensuring the transition of government economics from the primary goodsexporting to the innovative type of growth.

However, industrial policy legislation at the federal level does not contain the exact programs and measures capable of contributing to this goal realization [1, 2]. Regional mechanisms of industrial policy formation and development often are not systematic and cannot be regarded as the basis for the elaboration of the country's industrial development general plan. That is why the determination of the means of forming and developing the industrial policy at the federal level is considered to be an urgent research problem.

In our opinion, the most appropriate means of forming the industrial policy is applying the synergetic approach. According to this approach, market entities are regarded as self-organizing systems which not only interact with the environment and allow to conform to it, but also influence the environment by overcoming the uncertainty and taking into consideration the priority of non-linear innovations.

Aims and tasks. The present article is focused on examining the synergetic approach to forming the industrial policy as well as on integrated industrial structures (IIS) as one of the possible means. In order to achieve this aim, the following tasks are put forward:

1) to analyze the industrial policy influence on the intensification of the integration processes in economics;

2) to examine the essence of the synergetic approach in relation to managing economic systems;

3) to justify the positive economic effect arising from the integration contributing to the Russian industry development from the perspective of the synergetic approach.

Industrial policy and integration processes in economics. Industrial policy is a system of relationships among government bodies, business entities, scientific and social organizations regarding the formation of structurally balanced, competitive industry whose intellectual core is represented by the latest technological paradigm $[3,4]$ and received its legislative recognition in 2014 due to the adoption of the Federal Law no. 488-FZ «On industrial policy in the Russian Federation» of 31.12.2014.

Government industrial policy is aimed at ensuring the economic growth not only due to the quantitative expansion of production output, but also by increasing the part of high-tech and science intensive production, introducing various innovations into industrial processes, capable of creating a higher value added [5]. However, the Russian industry is now experiencing difficulties. According to Rosstat (Federal State Statistics Service), there is a considerable decrease in profits and production output of many branches in 2015 in comparison with 2014. Foreign sanctions, ruble exchange rate, investment activity decline have significantly decreased the development pace of industries and worsened their competitive position in the world market.

All this raises the problem of searching for possible means of increasing the effectiveness along with creating additional competitive advantages such as innovative products and services. Business entities integration, in particular, organizing integrated industrial structures (IIS) is regarded as one of these means.

IIS creation realizes one of the basic industrial policy principles: integration of science, education and industry. By joining efforts, participants can reduce costs of manufacturing the innovative products, increase the effectiveness of various innovations elaboration and augment input intensity.

Business entities integration is one of the most important tendencies of the economic transformations in Russia. The results of IIS work in the real sector of economy indicate the raising level of innovation activity, the increasing competitive ability of all branches of the Russian industry. For example, in 2013 the innovation activity of enterprises with more than 5000 personnel reached $73.9 \%$, while that of the enterprises with less than 100 personnel was just $5 \%$. What is more, the intensity of expenditures on various innovations in the enterprises are twice as big as this figure in small and medium businesses (Fig. 1). 


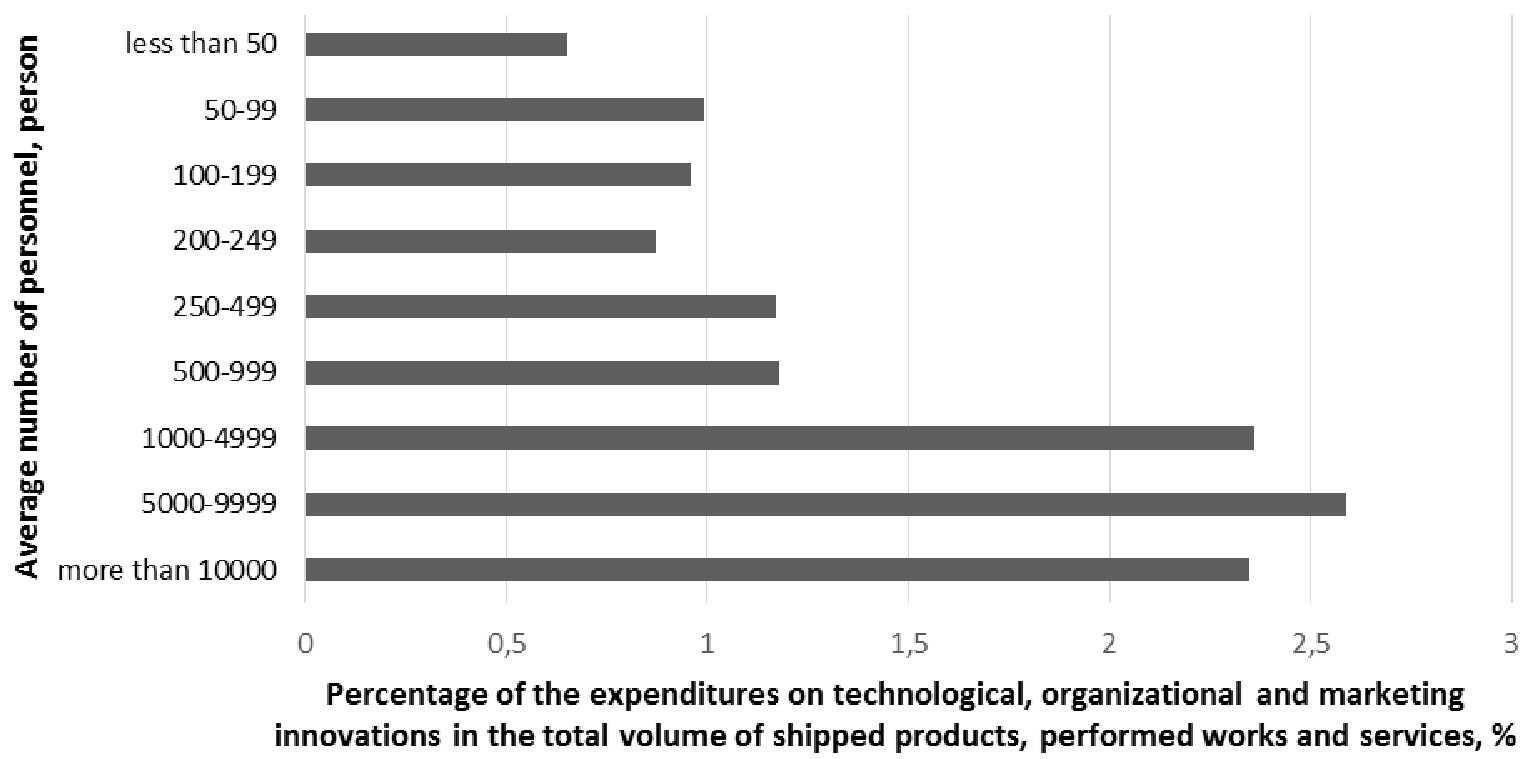

Fig. 1. The intensity of the expenditures on technological, organizational and marketing innovations ranging in accordance with enterprises size in 2007-2013

Prepared by the author on the basis of the statistics collection «Innovation activity indicators: 2015» [6]

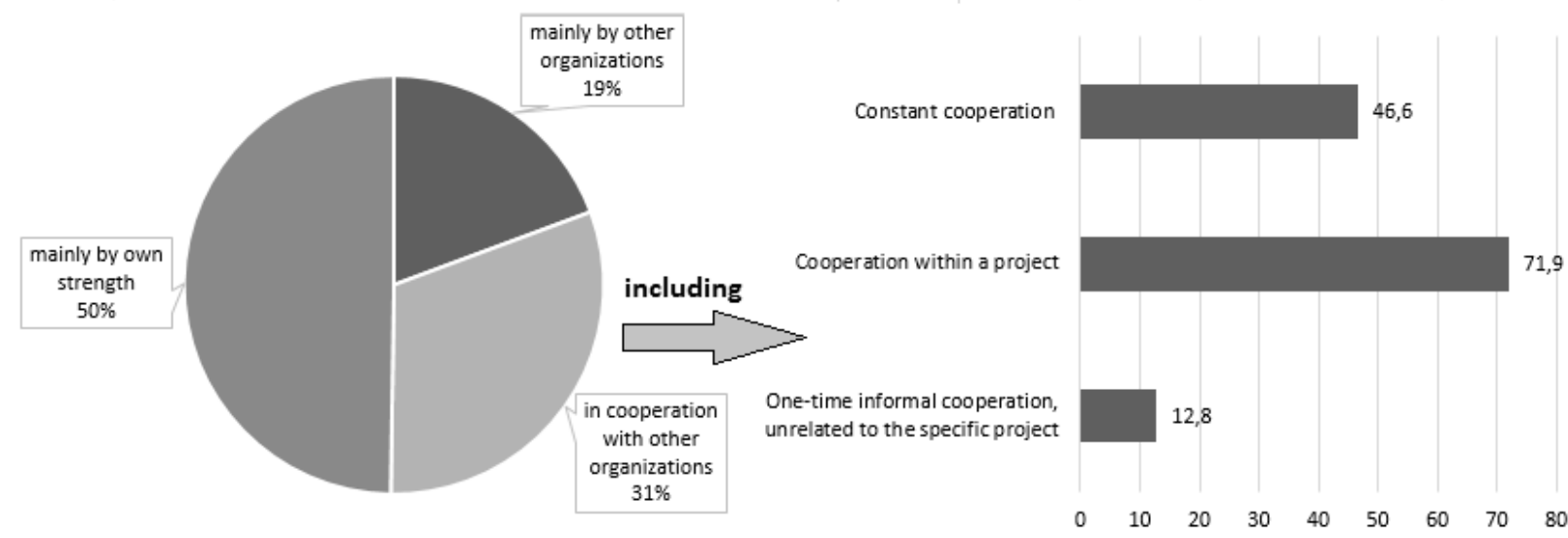

Fig. 2. Organizations distribution, participated in common projects, according to cooperation ties in percentage terms on average over a period of 2007-2013

Prepared by the author on the basis of the statistics collection «Innovation activity indicators: 2015»

In accordance with the statistics of 20072013, a third of all industrial enterprises cooperated with other organizations for the technological innovations elaboration. Regarding such hightech branches of industry as computer engineering and aircraft production, including spaceship production, in 2013 these figures were $40 \%$ and $44.6 \%$ correspondingly. What is more, $46 \%$ of all enterprises participating in common projects acted within constant cooperation (Fig. 2).

Corporate integration advantages are defined by the effects of combining resources, possibility of obtaining credits on favorable terms from incorporated financial structures, research and development economies of scale, new products and technological processes launching, common marketing strategy realization. By joining efforts, integrated enterprises achieve the synergetic effect, which arises from the expansion and intensification of industrial-engineering communications such as, for example, joint use of raw materials, energy and other resources, material and technical basis, the consolidation of capital and other. 
The synergetic approach implementing to economic systems management. Russian economists examining the nature of integration processes turn more often to the synergetic conception, which in contrast to the cybernetic approach (main management paradigm of the end of the 20th century) focuses on proactive system development, instead of the management depending on deviations or current tasks. Using the synergetics statements researchers managed to propose the thesis of the synergetic effect representing the result of the economic system transformation.

The term «synergetics» as an interdisciplinary branch of science investigating general rules of phenomena and processes in complex nonequilibrium systems on the basis of their characteristic principals of self-organization was introduced for the first time by German Haken in 1977 in his book «Synergetics» [7]. Synergy (after the Greek word «synergeia» - collaboration, commonwealth) is the summarizing effect of the interaction of two or more elements so that their joint operation exceeds significantly the effect of each separate element in their sum. Such Russian scientists as V.I. Arshinov, E.N. Knyazeva, S.P. Kurdyumov, V.A. Belavin, V.G. Budanov, Yu.A. Danilov, I.S. Dobronravova, I.A. Evin, G.G. Malinetskiy and others have been engaged in the research of synergetic effects. Nevertheless, the issue of the origin and the assessment of synergetic effects in economics remains insufficiently explored.

Integration processes strengthening, in particular, the formation of various integrated structures, clusters, interfirm partnership and others causes the interest in the research of the synergetic effect in economic systems. According to L.A. Musaev, the integration is mainly aimed at obtaining the synergetic effect, i. e., «the increase of the integrated companies' value which doesn't occur because of simple summarizing of their costs but due to a new cost addition» [8]. By cooperating, enterprises compensate their demerits and strengthen their merits in order to get the additional competitive advantage at the market.

O.V. Nesmachnykh and V.V. Litovchenko specify the following main integration advantages obtained due to the synergetic effect: innovations absorption acceleration, broad market coverage, cost saving and the increase in the efficiency of goods and services production, organizations flexibility improving [9]. As per R.Kh. Khasanov, the synergetic effect allows to reduce transactions expenses, external and internal risks, as well as to increase research and development costs of the integrated structure, to enhance the profitability and attract investments [10].

According to S.G. Avdonina, the synergetic effect arises from the fact that the ties among the integrated structure participants are being normalized and developed to become closer and more productive. In this case, the synergetic effect makes for such integration advantages as faster exchange of material and information resources, as well as establishing stronger connections with the enterprises within the integrated structure which allows carrying out joint projects, strengthening the market position and entering new markets [11].

Thus, the synergetic approach to managing economic systems, including IIS, provides proactive system development, instead of the management depending on deviations or current tasks. In accordance with this approach, a market entity shall have the following qualities: flexibility, immediate reaction to the changes of customer demand, external conditions adaptation, which is true for IIS, as the majority of IIS are diversified structures, hence steady to risks and the external environment ambiguity.

In our opinion, applying the synergetic concept to forming the industrial policy is justified and essential at this stage of development. Integrated structures, in which the synergetic effect occurs, serve as the foundation of the developed countries' economics. These structures function successfully for more than fifty years, thus, they may be regarded as a means of implementing the synergetic approach for forming the industrial policy.

Integration as a means of the synergetic conception implementing. Let us examine the mechanism of the synergetic effect appearing in IIS with the help of the main marginal analysis theses. In accordance with this concept, the behavior of industrial enterprises of a certain manufacturing industry in the market will be similar to that of a monopolistic competitor, which is true if a region or the whole country are regarded as a market.

Let us suppose that there are two enterprises of a certain manufacturing industry, functioning in the market of monopolistic competition. Demand functions and total costs functions of the production have been determined for each of the two enterprises (see Tab. 1). 
Table 1

\begin{tabular}{|l|c|c|}
\hline Given data & \multicolumn{1}{|c|}{ Enterprise \#1 } & \multicolumn{1}{|c|}{ Enterprise \#2 } \\
\hline $\begin{array}{l}\text { Demand } \\
\text { function }\end{array}$ & $\begin{array}{l}|c| \\
\mathrm{D}_{1}=\mathrm{A}_{1}-\mathrm{B}_{1} \mathrm{Q}, \\
\text { where } \mathrm{A}_{1} \text { и } \mathrm{B}_{1} \text { are the constants, measurable } \\
\text { within the range of }(0, \infty)\end{array}$ & $\begin{array}{l}\mathrm{D}_{2}-\mathrm{B}_{2} \mathrm{Q} \\
\text { where } \mathrm{A}_{2} \text { и } \mathrm{B}_{2} \text { are the constants, measurable } \\
\text { within the range of }(0, \infty)\end{array}$ \\
\hline $\begin{array}{l}\text { Total costs } \\
\text { function }\end{array}$ & $\begin{array}{l}\mathrm{TC}_{1}=\mathrm{a}_{1} \mathrm{Q}^{2}+\mathrm{b}_{1} \mathrm{Q}+\mathrm{c}_{1} \mathrm{Q}^{2}+\mathrm{b}_{2} \mathrm{Q}+\mathrm{c}_{2} \\
\text { where } \mathrm{a}_{1}, \mathrm{~b}_{1}, \mathrm{c}_{1} \text { are the constants, measurable } \\
\text { within the range of }(0, \infty) \\
\text { The expression } \mathrm{a}_{1} \mathrm{Q}^{2}+\mathrm{b}_{1} \mathrm{Q} \text { describes variable } \\
\text { costs } \mathrm{VC}_{1}, \text { constants } \mathrm{c}_{1} \text { are the fixed costs } \mathrm{FC}_{1} .\end{array}$ & $\begin{array}{l}\text { where } \mathrm{a}_{2}, \mathrm{~b}_{2}, \mathrm{c}_{2} \text { are the constants, measurable } \\
\text { within the range of }(0, \infty) \\
\text { The expression } \mathrm{a}_{2} \mathrm{Q}^{2}+\mathrm{b}_{2} \mathrm{Q} \text { describes variable } \\
\text { costs } \mathrm{VC}_{2}, \text { constants } \mathrm{c}_{2} \text { are the fixed costs } \mathrm{FC}_{2} .\end{array}$ \\
\hline
\end{tabular}

Table 2

\begin{tabular}{|c|c|c|}
\hline Indices & $\begin{array}{l}\text { Common for the enterprises } \\
\qquad \# 1 \text { and } \# 2\end{array}$ & For IIS with respect to the synergetic effect \\
\hline Demand & & $\mathrm{D}=\mathrm{A}_{1}-\mathrm{B}_{1} \mathrm{Q}+\mathrm{A}_{2}-\mathrm{B}_{2} \mathrm{Q}$ \\
\hline Marginal yield & & $\mathrm{MR}=0,5\left(\mathrm{~A}_{1}-\mathrm{B}_{1} \mathrm{Q}+\mathrm{A}_{2}-\mathrm{B}_{2} \mathrm{Q}\right)$ \\
\hline Variable costs & $\begin{aligned} \mathrm{VC}_{\text {comm }}= & a_{1} \mathrm{Q}^{2}+\mathrm{b}_{1} \mathrm{Q}+\mathrm{a}_{2} \mathrm{Q}^{2}+ \\
& +\mathrm{b}_{2} \mathrm{Q}\end{aligned}$ & $\begin{array}{l}\qquad \mathrm{VC}_{\text {IIS }}^{\mathrm{S}}=(1-\alpha)\left(\mathrm{a}_{1} \mathrm{Q}^{2}+\mathrm{b}_{1} \mathrm{Q}+\mathrm{a}_{2} \mathrm{Q}^{2}+\mathrm{b}_{2} \mathrm{Q}\right) \\
\text { where } \alpha \text { is the relative reduction of IIS variable costs compared } \\
\text { with the sum of the enterprises variable costs before the integration }\end{array}$ \\
\hline Fixed costs & $\mathrm{FC}_{\text {comm }}=\mathrm{c}_{1}+\mathrm{c}_{2}$ & $\begin{array}{l}\qquad \mathrm{FC}_{\text {IIS }}^{\mathrm{S}}=(1-\beta)\left(\mathrm{c}_{1}+\mathrm{c}_{2}\right) \\
\text { where } \beta \text { is the relative reduction of IIS fixed costs compared } \\
\text { with the sum of the enterprises fixed costs before the integration }\end{array}$ \\
\hline Total costs & $\mathrm{TC}_{\text {comm }}=\mathrm{VC}_{\text {comm }}+\mathrm{FC}_{\text {comm }}$ & $\mathrm{TC}_{\mathrm{IIS}}^{\mathrm{S}}=\mathrm{VC}_{\mathrm{IIS}}^{\mathrm{S}}+\mathrm{FC}_{\mathrm{IIS}}^{\mathrm{S}}$ \\
\hline Marginal costs & $\mathrm{MC}_{\text {comm }}=2 \mathrm{a}_{1}+\mathrm{b}_{1}+2 \mathrm{a}_{2}+\mathrm{b}_{2}$ & $\mathrm{MC}_{\mathrm{IIS}}^{\mathrm{S}}=\mathrm{MC}_{\text {comm }}-\alpha \mathrm{MC}_{\text {comm }}$ \\
\hline $\begin{array}{l}\text { Equilib- } \\
\text { rium quantity }\end{array}$ & $Q_{e q}=\frac{A_{1}+A_{2}-2 b_{1}-2 b_{2}}{4 a_{1}+4 a_{2}+B_{1}+B_{2}}$ & $Q_{e q}^{S}=\frac{A_{1}+A_{2}-2 b_{1}-2 b_{2}+2 \alpha b_{1}+2 \alpha b_{2}}{4 a_{1}+4 a_{2}-4 \alpha a_{1}-4 \alpha a_{2}+B_{1}+B_{2}}$ \\
\hline \multicolumn{2}{|c|}{ The synergetic effect } & $\begin{array}{c}\mathrm{SE}^{*}=\mathrm{TC}_{\text {comm }}-\mathrm{TC}^{\mathrm{S}}{ }_{\text {IIS }}=\alpha \mathrm{VC}_{\text {comm }}+\beta \mathrm{FC}_{\text {comm }} \\
\mathrm{SE}^{* *}=\mathrm{D}_{\text {comm }} \mathrm{Q}_{\text {eq }}-\mathrm{TC}_{\text {comm }}-\mathrm{D}_{\text {IIS }}^{\mathrm{S}} \mathrm{Q}_{\text {eq }}^{\mathrm{c}}+\mathrm{TC}_{\text {IIS }}^{\mathrm{c}}\end{array}$ \\
\hline
\end{tabular}

* calculated at $\mathrm{Q}=\mathrm{Q}_{\mathrm{eq}}$

*** where $\mathrm{D}_{\text {comm }}$ and $\mathrm{TC}_{\text {comm }}$ are calculated at $\mathrm{Q}=\mathrm{Q}_{\mathrm{eq}}, \mathrm{D}^{\mathrm{S}}{ }_{\mathrm{IIS}}$ and $\mathrm{TC}_{\text {IIS }}^{\mathrm{S}}$ is calculated at $\mathrm{Q}=\mathrm{Q}_{\text {eq }}^{\mathrm{S}}$

Supposing that these enterprises have merged, their demand functions and total costs functions will be summed up, if the production output remains the same. However, in practice the enterprises gain the benefit from the integration which could be in the form of reducing both fixed (rent, insurance payments, etc.) and variable costs (expenditures on raw and other materials, transport expenditures etc.) (see Tab. 2).

The synergetic effect in this context is represented in value units as the economy in IIS total costs. What is more, it is worth emphasizing that the economy arises not only due to the economy of scale, but also due to the more effective use of intellectual, scientific and technical potential of the integrated enterprises.
In the first variant, the synergetic effect is obtained in case the IIS production output does not increase relative to the production output of the enterprises before the integration (see Fig. 3).

The situation shown in Fig. 3 is not optimal for IIS, since a short-term equilibrium at the market, $M R=M C_{\text {IIS }}^{\mathrm{S}}$, is not obtained. Fig. 4 represents the case when by increasing the output from $\mathrm{Q}_{\mathrm{eq}}$ to $\mathrm{Q}_{\text {eq }}^{\mathrm{S}}$ and decreasing the price from $\mathrm{P}_{\mathrm{eq}}$ to $\mathrm{P}_{\text {eq }}^{\mathrm{S}}$, the IIS moves into an equilibrium state and receives the economic profit of the size $\mathrm{DQ}_{\text {eq }}^{\mathrm{S}}-\mathrm{TC}_{\text {IIS. In this case, the }}^{\mathrm{S}}$ synergetic effect will be equal to the difference between IIS economic profit and the consolidated economic profit of the enterprises \# 1 and \# 2 (see Tab. 2). 


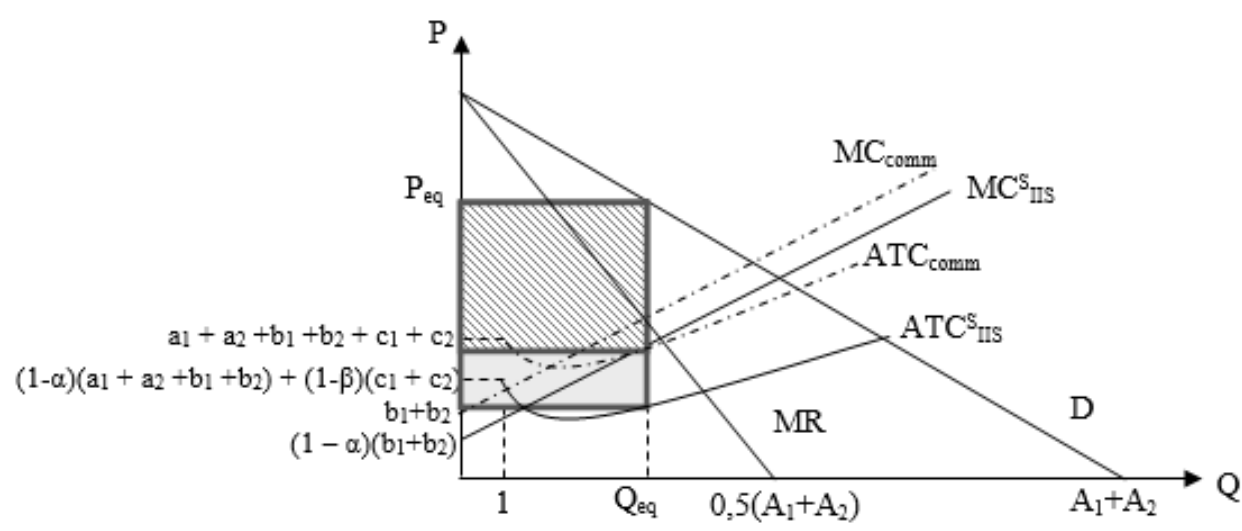

Consolidated economic profit of the enterprises \#1 and \# 2

IIS synergetic effect, at $\mathrm{Q}=\mathrm{Q}_{\mathrm{eq}}$

Fig. 3. IIS synergetic effect at $\mathrm{Q}=\mathrm{Q}_{\mathrm{eq}}$

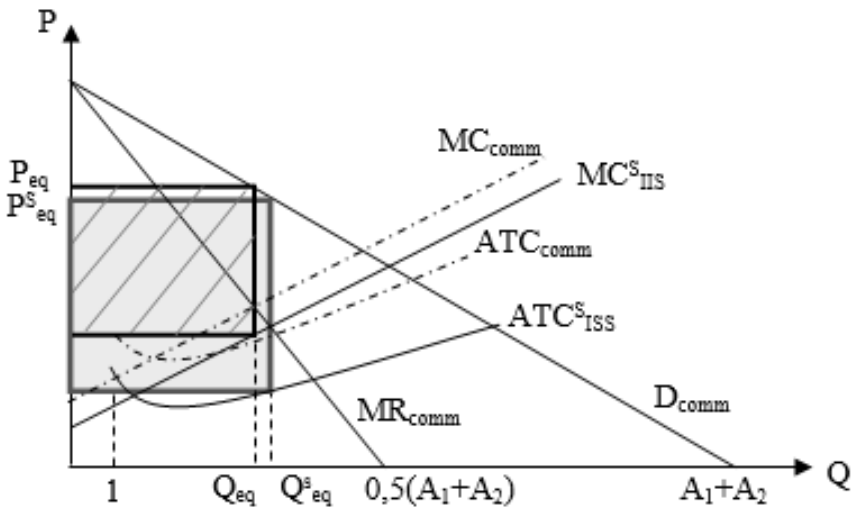

IIS economic profit at $Q=Q^{S}$ eq

Consolidated economic profit of the enterprises \#1 and \# 2

Fig. 4. IIS synergetic effect at $\mathrm{Q}=\mathrm{Q}_{\text {eq }}^{\mathrm{s}}$

The above-described cases are true only for a short-term period of IIS functioning. Over a longterm period the obtained economy $(1-\alpha) \mathrm{VC}_{\text {comm }}$ и $(1-\beta) \mathrm{FC}_{\text {comm }}$ is lost due to inflation processes, technologies and equipment aging, management errors, competitive ability decrease and other reasons; along with this economy reduction the synergetic effect is lost.

The article authors propose to use marginal costs as the synergetic effect indicator for a longterm period, since they reveal the trend of both variable and fixed costs changing in the whole. Over a short-term period the difference between $\mathrm{MC}_{\text {comm }}$ and $\mathrm{MC}_{\text {IIS }}^{\mathrm{S}}$ will make $\alpha\left(\mathrm{b}_{1}-\mathrm{b}_{2}\right)$ value units, however, in course of time with the fixed
Q marginal costs will start to increase, and the synergetic effect will decrease (see Fig. 5).

We propose to consider the presented synergetic effect as the second-order power function:

$$
\mathrm{SE}=\mathrm{nt}^{2}+\mathrm{mt}+\beta\left(\mathrm{c}_{1}+\mathrm{c}_{2}\right),
$$

$$
\text { if }\left\{\begin{array}{l}
\mathrm{n}<0, \mathrm{n}=\mathrm{const}, \\
\mathrm{m}>0, \mathrm{~m}=\mathrm{const}, \\
\mathrm{MC}_{\mathrm{comm}}-\mathrm{MC}_{\mathrm{IIS}}^{\mathrm{s}}=\alpha\left(\mathrm{b}_{1}+\mathrm{b}_{2}\right), \mathrm{C} \ni \in\left[0, \mathrm{t}^{*}\right], \\
\mathrm{MC}_{\text {comm }}-\mathrm{MC}_{\mathrm{IIS}}^{\mathrm{s}}<\alpha\left(\mathrm{b}_{1}+\mathrm{b}_{2}\right), \mathrm{C} \ni \in\left[\mathrm{t}^{*} ; \infty\right], \\
\mathrm{Q}=\text { const. }
\end{array}\right.
$$




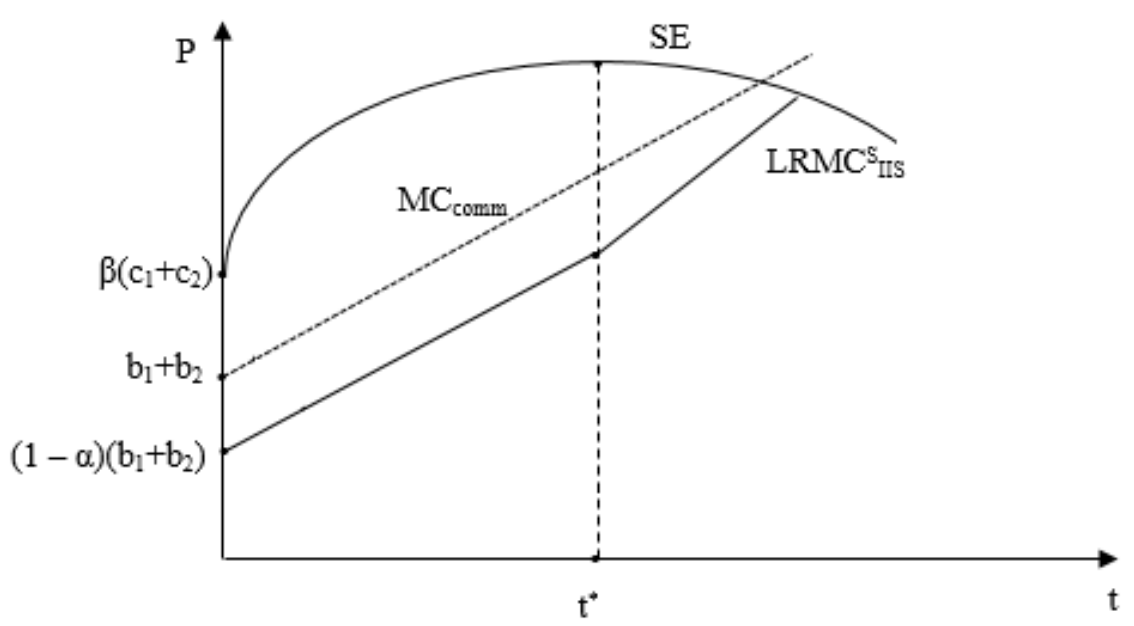

Fig. 5. The change of the IIS synergetic effect change at $\mathrm{Q}=$ const

Thus, the synergetic effect occurs in IIS at the moment of the integration, but in the course of time it disappears, if there are no efforts to increase the IIS activities efficiency: entering new markets, new technologies development, production diversification and others [12, 13]. However, the experience shows that IIS as a self-organizing system is capable of responding flexibly to external actions by some internal environment transformation, consequently, it is possible to suppose that at some period of time $t_{i} \in\left[0 ; t^{*}\right]$ a new synergetic effect SEti appears in IIS after a management decision $d$.

Along with that in order to increase the efficiency of the market entities activities, including IIS, it is required to take appropriate supportive measures, which is one of the main goals of the industrial policy [14]. In our opinion, forming the industrial policy shall be carried out on the feedback principle: on the one hand, the government creates the means for developing the industry, comprising the ones for IIS appearance, and on the other hand, responds to the problems arising during their implementation. For example, in case of IIS it is required to develop measures for stimulating innovation development, breaking into new markets, but at the same time for restricting them in case monopoly power tends to appear.

Findings. Thus, determining the methods for forming the industrial policy and developing it at the federal level is an important research problem, since the efficiency of these methods has a direct impact on the economic and innovation development of the branches of the Russian industry. The synergetic approach to forming the industrial policy serves not only as the quantitative component of the effectiveness increase of market entities functioning, but also as its qualitative component, which is the essential condition of effective innovation development of the economics as a whole.

During the research, the following results have been obtained:

1) the influence of the industrial policy on integration processes strengthening in economics has been analyzed, statistics data have been examined, which permit to draw conclusion on IIS activities influence on the increasing of the innovation development level of the Russian industry;

2) the notion synergetic effect has been revealed, the essence of the synergetic approach to the economic systems management has been examined;

3) the principle of the synergetic effect appearance in IIS on the basis of the marginal analysis has been examined, the positive economic effect appeared from the integration contributing to the Russian industry development from the perspective of the synergetic approach has been justified.

Directions for further research. Promising directions for further research seem to be connected with developing a procedure for assessing the IIS synergetic effect, as well as with elaborating the business mechanism for managing the IIS innovation potential.

The article has been prepared as part of the study conducted within the project no. 26.1303.2014/K of the Ministry of Education and Science of the Russian Federation on academic research within the scope of the project part of the government assignment 


\section{REFERENCES}

1. Glukhov V.V., Zvagel'skii V.F. Features of the industry in the open economy. St. Petersburg State Polytechnical University Journal. Economics, 2012, no. 2-1(144). pp. 7-12. (rus)

2. Karlik A.E., Rohchin V.E., Novikov Yu.I. Management of industrial development of Russia northwest: the analysis of the condition and the improvement way. St. Petersburg State Polytechnical University Journal. Economics, 2012, no. 2-2(144). pp. 43-48. (rus)

3. Babkin A.V., Plotnikov V.A., Muraveva S.V. Integrated industrial structures in the economy of Russia: organizational forms and typology. Proceedings of The 25th International Business Information Management Association Conference, May 7-8, 2015 Amsterdam, Netherlands, pp. 1286-1294.

4. Babkin A.V., Kudryavtseva T.J., Bakhmutskaya A.V. Problems and the directions of formation of industrial policy of the region (on the example of St. Petersburg). News of St. Petersburg State University of Economy and Finance, 2011, no. 4(70), pp. 27-34. (rus)

5. Babkin A.V., Bakhmutskaya A.V., Kudryavtseva T.J. Formation of the effective mechanism of the industrial policy of the region. Economic Revival of Russia, 2013, no. 4(38). pp. 204-212. (rus)

6. Myasnyankina O.V. Leading role of the industrial policy in the regions development. InVestRegion. 2008. № 1. pp. 12-16. (rus)

7. Innovation activities indicators: 2015: statistics collection. Moscow, National Research University Higher School of Economics, 2015. 320 p. (rus)

8. Haken G. Synergetics. Moscow, Mir, 1980. 388 p. (rus)

9. Musaev L.A. Assessment of the synergetic effect of the economic systems. Bulletin of YuRGTU (NPI), 2011, no. 3, pp. 132-137. (rus)

10. Nesmachnykh O.V., Litovchenko V.V. The synergetic effect appearance in the economic cluster on the basis of the increasing return rule. Fundamental research, 2013, no. 6, pp. 1220-1223. (rus)

11. Khasanov R.Kh. Cluster synergetic effect. Problems of modern economics. URL: http://www.m-economy.ru /art.php?nArtId=2784 (accused February 04, 2015). (rus)

12. Avdonina S.G. Quantitative methods of the synergetic effect assessment of the innovation cluster. Economic system management. URL: http://www.uecs. ru/uecs-39-392012/item/1147-2012-03-19-08-23-46 (accused February 01, 2015). (rus)

13. Galeeva E.I. Elaboration of industrial enterprise development scenarios with the help of the synergetic model. News of Orenburg State University, 2010, no. 8(114), pp. 118-123. (rus)

14. Anikina I.D. Synergetic effect creation in mergers and acquisitions. Finances and business, 2009, no. 2, pp. 47-52. (rus)

15. Serkov L.A. Synergetic modelling of the economic growth with the consideration of companies mergers and acquisitions. Bulletin of Chelyabinsk State University. Economics, 2009, no. 9(147), pp. 113-117. (rus).

16. Babkin A.V., Vertakova Yu.V. Methods for the assessment of the economic potential of an industrial enterprise: analysis and characterization. Proceedings of The 25th International Business Information Management Association Conference "Innovation Vision 2020: From Regional Development Sustainability to Global Economic Growth», 2015, pp. 1294-1302.

\section{СПИСОК ЛИТЕРАТУРЫ}

1. Глухов В.В., Звагельский В.Ф. Особенности функционирования промышленности в условиях открытой экономики // Научно-технические ведомости Санкт-Петербургского государственного политехнического университета. Экономические науки. 2012. № 2-1(144). С. 7-12.

2. Карлик А.Е. Управление промышленным развитием Северо-Запада России: анализ состояния и пути совершенствования // Научно-технические ведомости Санкт-Петербургского государственного политехнического университета. Экономические науки. 2012. № 2-2(144). С. 43-48.

3. Babkin A.V., Plotnikov V.A., Muraveva S.V. Integrated industrial structures in the economy of Russia: organizational forms and typology // Proceedings of The 25th International Business Information Management Association Conference, May 7-8, 2015 Amsterdam, Netherlands, pp. 1286-1294.

4. Babkin A.V., Kudryavtseva T.J. Identification and Analysis of Instrument Industry Cluster on the Ter- ritory of the Russian Federation // Modern Applied Science, 2015, vol. 9, no. 1, pp. 109-118.

5. Бабкин А.В., Бахмутская А.В., Кудрявцева Т.Ю. Разработка эффективного механизма промышленной политики региона // Экономическое возрождение России. 2013. № 4(38). С. 204-212.

6. Мяснянкина О.В. Определяющая роль промышленной политики в развитии регионов // ИнВестРегион. 2008. № 1. С. 12-16.

7. Индикаторы инновационной деятельности: 2015: стат. сборник. М.: Национальный исследовательский университет «Высшая школа экономики», 2015. $320 \mathrm{c}$.

8. Хакен Г. Синергетика. М.: Мир, 1980. 388 с.

9. Мусаев Л.А. Оценка синергетического эффект экономических систем // Вестник ЮРГТУ (НПИ). 2011. № 3. С. 132-137.

10. Несмачных О.В., Литовченко В.В. Формирование синергетического эффекта в экономическом кластере на основе закона возрастающей от- 
дачи // Фундаментальные исследования. 2013. № 6. C. $1220-1223$.

11. Хасанов P.X. Синергетический эффект кластера // Проблемы современной экономики. URL: http://www.m-economy.ru/art.php?nArtId=2784 (дата обращения: 04.02.2015).

12. Авдонина С.Г. Количественные методы оценки синергетического эффекта инновационного кластера // Управление экономическими системами. URL: http://www.uecs.ru/uecs-39-392012/item/11472012-03-19-08-23-46 (дата обращения: 01.02.2015).

13. Галеева Е.И. Разработка сценариев развития промышленного предприятия с помощью синергетической модели // Вестник Оренбургского государственного университета. 2010. № 8(114). С. 118-123.
14. Аникина И.Д. Создание синергетических эффектов в сделках слияний и поглощений // Финансы и бизнес. 2009. № 2. С. 47-52.

15. Серков Л.А. Синергетическое моделирование экономического роста с учетом слияний и поглощений компаний // Вестник Челябинского государственного университета. Экономика. 2009. № 9(147). C. $113-117$.

16. Babkin A.V., Vertakova Yu.V. Methods for the assessment of the economic potential of an industrial enterprise: analysis and characterization // Proceedings of The 25th International Business Information Management Association Conference «Innovation Vision 2020: From Regional Development Sustainability to Global Economic Growth», 2015 p. 1294-1302.

ZDOLNIKOVA Svetlana V. - Peter the Great St. Petersburg Polytechnic University.

195251. Politechnicheskaya str. 29. St. Petersburg. Russia. E-mail: s.v.muraveva@yandex.ru

ЗДОЛЬНИКОВА Светлана Вячеславовна - аспирант Санкт-Петербургского политехнического университета Петра Великого.

195251, ул. Политехническая, д. 29, Санкт-Петербург, Россия. E-mail: s.v.muraveva@yandex.ru

BABKIN Aleksandr V. - Peter the Great St. Petersburg Polytechnic University.

195251. Politechnicheskaya str. 29. St. Petersburg. Russia. E-mail: babkin@spbstu.ru

БАБКИН Александр Васильевич - профессор кафедры «Экономика и менеджмент в машиностроении» Санкт-Петербургского политехнического университета Петра Великого, доктор экономических наук, профессор.

195251, ул. Политехническая, д. 29, Санкт-Петербург, Россия. E-mail: babkin@spbstu.ru 